\title{
Analysis of Financial Performance Based on the Du Pont Method at PT Perkebunan Nusantara Xiv Oil Palm Plant
}

\author{
Muhammad Nasrulah \\ Management Department, Faculty of Economy and Social, State University of Makasar, \\ Indonesia \\ Received: August 2, 2020 \\ Received in Revised: August 11, 2020 \\ Accepted: August 13, 2020
}

\begin{abstract}
ROI is the Net Profit Margin multiplied by the asset turnover. Companies that develop this analysis system are often called the Du Pont system or ROI with the Du Pont approach. This study is a study to determine the level of performance. In this study, the variables to be studied are: Net Profit Margin, Asset Turn Over, Net Income and Total Asset as measured by the Du Pont Method. This study uses time series data for the last five years, so that the population of this study is also the research sample. Based on the considerations stated above, the authors are interested in conducting research with the title: "Analysis of Financial Performance Based on the Du Pont Method.
\end{abstract}

Keywords: Du Pont, Profitibality, Financial, Management

\section{Introduction}

The performance of a company is the result of a series of activities carried out by the company within a certain period of time. One source of information to find out and measure company performance is financial reports. The Indonesian Institute of Accountants in Financial Accounting Standards, Anonymous (2002: 4) "states that the purpose of financial statements is to provide information regarding the financial position, performance and changes in the financial position of a company that is beneficial to a large number of users in making economic decisions". Sawir (2003: 2) suggests "that the media that can be used to examine the health condition of a company is financial statements".

The performance appraisal of a company cannot be separated from the influence of the resources that the company is engaged in. Collies and Montgomery (1997: 9) argued that "Resources are a very important strategic building block because they determine what a company can do." Resources are a company's long-term capital that determines not only its competitive advantage, but also the market opportunities it can serve.

Palm Oil is one of the commodities produced by the plantation business the production level is quite large but the level of sales is very small when compared to Sumatra and Kalimantan. This level of sales is due to lack of production and lack of supervision. the oil palm business provides an important contribution to the company, both from the point of view of annual sales results. In the table above, sales of palm oil in a period of 5 years have increased and decreased, it can be seen that in 2001-2002 sales increased by $35.18 \%$, in $2002-2003$ sales had increased by $3.31 \%$, as well as in 2003-2004 had increased $22,96 \%$ but in 2005 sales decreased by $29.01 \%$ 
Efficiency in all fields has been carried out to improve the company's financial performance. Currently, the company is preparing to launch its inaugural production to be marketed overseas. Until now, it has signed several contracts for the purchase of palm oil production in attractive packaging for domestic European, Middle Eastern, Asian and African countries. This condition is expected to open up great opportunities for long-term investment and increase sales and production in the future. The current condition brings great wisdom in attitude and thinking so that palm oil production increases because increased production will also have an effect on increased sales. Palm is one of the commodities produced by the plantation business which is spread throughout Indonesia both in the East and West Indonesia Region. The area of land that is potential and available for oil palm development in Eastern Indonesia and West Indonesia is 2,487,256 Ha with the following details: If the potential for land that is suitable for the technical culture of Oil Palm in KTI is quite large, while those already planted are still very large. far below the KBI figure, why is that happening. Does this business opportunity not promise an incentive for the business world so that it is not interested in investing in the palm oil business in KTI? These questions are very interesting to find answers to.By looking at the prospects for developing oil palm plantations in Indonesia in general and particularly in eastern Indonesia, PKS Luwu I as a pilot project has a strategic role and is therefore interesting to study. Based on the considerations that have been stated above, the authors are interested in conducting research with the title: "Analysis of Financial Performance Based on the Du Pont Method.

\section{Financial management}

The notion of financial management always changes from time to time in accordance with the development and goals to be achieved. Financial management is a function that cannot be separated from other functions in a company, such as a marketing function, a production function and a personnel function because financial management is a function that is responsible for the company's survival and how to obtain and allocate company funds efficiently and effectively. so that the company's goals can be achieved. Based on the foregoing and seeing the development of the business world today, many companies, both managed by the government and the private sector, which are engaged in various business fields, always pay greater attention to corporate financial problems, especially management of sources and use of funds. To define the definition of financial management, it is necessary to first identify the functions and duties of financial management. The following are some of the limitations put forward by the author, among others, Horne and Wachowicz, which translated by Sutojo (1997: 2) states that: "Financial management is all activities related to the acquisition, funding and management of assets with several overall objectives". Meanwhile, according to Husnan and Pudjiastuti (1998: 4) that: "Financial management involves planning, analyzing and controlling financial activities".

From some of the limitations put forward by the authors above, it can be concluded that the meaning and function of financial management is related to how a manager is able to manage a company in obtaining funds and allocating funds effectively and efficiently so that the company's goals are achieved. In principle, company management demands that both obtaining and using funds must be based on considerations of efficiency and effectiveness. Thus, company spending or financial management is nothing but management for spending functions. In terms of management, it contains planning, directing and controlling functions. In connection with that, it is necessary to have good planning and control in using and in fulfilling funding needs.

\section{Company Financial Performance}


So far there has been no uniformity in defining performance, there are those who choose performance as the implementation of operational activities, there are also those who have more performance as the work performance of an organization. In principle, performance can be seen from who gives the assessment. For management, performance is a contribution that can be given by a particular section for the achievement of overall goals. Meanwhile, for those outside management, performance is a tool that measures the achievements of a company in a certain period that reflects the level of results of activity implementation

So management has a dual interest in financial performance analysis, namely assessing the efficiency and profitability of operations, and weighing how effectively the company's resources are used. The assessment of operations is mostly carried out based on the analysis of the income statement, while the effectiveness of the use of company resources is usually measured by reviewing both the balance sheet and the profit and loss account. One way to assess the company's performance is to conduct an analysis of financial statements made in accordance with Indonesian Accounting Principles. Financial statement analysis tools include analysis of sources and use of funds (Fund Flow), comparative analysis, trend analysis, Lavarege analysis, Break Even analysis, financial ratio analysis and others. Financial performance is the result of a financial process that is reflected in financial statements that reflect the level of soundness in a certain period by using various resources or capital owned.

Djarwanto (1996: 62-63) argues that "financial reports from year to year can be analyzed by studying the direction of the trend". Trend in percentage is calculated by selecting the first year as the basis for comparison or as the base year. Trend as a percentage is basically an index number, showing the relative change of financial data over a period of time. Based on the definition of trend above, it can be concluded that trend analysis is a method of analysis by selecting the first year as the base year, where the base year is usually given a value of $100 \%$ and the following year shows the relative changes in financial data over a certain period of time. From the trend analysis it can be seen that the development of the company, for example, is the downward trend in sales from year to year accompanied by issuing bonds that have fixed expenses (interest), basically this condition indicates an unhealthy financial development. Furthermore, to analyze the company's financial condition using ratios, financial analysts can do it in two ways, namely cross-sectional techniques, namely the way of analysis by comparing the ratios between other similar companies at the same time. Time-series techniques, namely a way of analysis by comparing the financial ratios of a company from one period to another.

Cross-sectional techniques are useful for seeing the performance of a company relative to other similar industries or companies, while Time-series techniques are useful for finding out a trend towards an increase or decrease in performance during the analysis period. Both analysis techniques are used in this study. Financial performance is the result of a financial process that is reflected in financial statements that reflect the level of soundness in a certain period by using various resources or capital owned. In the Big Indonesian Dictionary, Anonymous (2002: 570) "Performance is defined as something that is achieved, demonstrated achievement and work ability." Meanwhile, Martono (2003: 52) says that "Financial performance is an assessment of the company's financial condition which can be information both past, present and future." From the definition above, it can be concluded that financial performance is a description of the financial condition and performance or results of operations of the company in a certain period. Or it can be concluded that performance is the resulting achievement that shows the implementation of the company's operations in achieving its goals. 


\section{Basics of Financial Statements}

Each component in the financial statements is also an ethical unit and the best is one another, so that in using it, it needs to be seen as a whole for its use so that there is no misunderstanding. Meanwhile, according to Sawir (2003: 5) that "financial statements are balance sheets, income statements, reports of changes in financial position (reports of sources and use of funds) which are interconnected" Balance sheet is a report on the financial position of a company on a certain date which includes assets, debt and capital. Assets are the resources owned by the company, while debt and capital show how these resources are spent by the company. The income statement is a report on the results of the company's operations in a financial statement According to Rahardjo (2000: 18) that the accountability report of the manager or company leader for the management of the company is entrusted to him to parties outside the company; namely company owners, government, creditors, and other interested parties. According to the Indonesian Institute of Accountants, Anonymous (2002: 2): "Financial reports include balance sheets, income statements, company statements of financial position, notes and other reports as well as explanatory material that is an integral part of financial statements". Financial reports are prepared or prepared with the intention of providing an overview or periodic progress reports made by the management concerned.

Financial statement analysis is an information tool needed by both internal parties in the company, in this case the company leadership and external parties, namely creditors and investors. For company leaders, this information is useful for knowing the conditions or circumstances as well as the development of the company, where the leadership can take the right policies and decisions, in order to achieve the goals desired by the company. Meanwhile, for creditors and investors, information on a company's financial statements is useful for making decisions regarding the right to grant and refuse credit. In other words, that the need for creditors to analyze the financial statements of a company is a security measure for themselves to determine the appropriateness of providing credit, so that the decision taken is really the right decision. And for investors, analyzing a company's financial statements is useful for determining its investment policy.

Thus, it is clear that interpreting and analyzing the financial statements of a company is very important for the parties having an interest in the company concerned even though their respective interests are different. And to assess the company's financial condition and performance, financial analysis requires several benchmarks. Benchmarks that are often used are ratios or indexes that connect two financial data with one another. The financial statement is the final result of the accounting process which describes the financial position of a company consisting of 3 main reports, namely (a) balance sheet, (b) report on the calculation of profit loss.periode tertentu. Laporan perubahan posisi keuangan yang sering disebut laporan sumber dan penggunaan dana adalah laporan yang mempunyai peranan penting dalam memberi informasi mengenai berapa besar dan kemana saja digunakan serta darimana sumber dana itu diambil.

\section{Financial Ratios}

A ratio is a number that shows the relationship between one element and other elements in the financial statements. Financial reports are the most important media for assessing the 
achievements and economic conditions of a company. According to Harahap (2002: 105) that: "Financial reports describe the financial condition and results of operations of a company at a certain time or for a certain period of time". Meanwhile, according to Harahap (2002: 298), it provides the following limitations: "Financial ratios are the numbers obtained from the results of comparisons of one financial statement item with another item that has a relevant and significant (meaningful) relationship ".

In this discussion, financial ratio analysis and trend analysis are used to assess company performance. These ratios are useful for showing changes in financial conditions or operating performance. Trend analysis describes these trends and patterns of change which in turn can show an analysis of risks and opportunities for the company being studied. The definition of ratio analysis according to the dictionary of financial and investment terms is an analytical method used in making credit and investment assessments and uses the relationship between numbers. numbers found in financial statements for assessing value and assessing risk. These ratios are compared with the ratios of the previous period and the ratios of other companies in order to reveal trends and identify irregularities. Djarwanto (1996: 123) states that "the ratio in financial statement analysis is a number that shows the relationship between an element and other elements in the financial statements".

Furthermore, the definition of financial ratios as described by Horne (1997: 133) is as follows: "to evaluate the company's financial condition and performance, financial analysts must conduct an examination of the company's financial health". The tools that can be used in this examination are financial ratios or indexes that connect two financial data by sharing one data with other data. Based on the above meanings of ratio analysis, it can be concluded that ratio analysis is one of the analytical methods to assess financial conditions. and company performance using ratio calculations on a quantitative basis, which shows the relationship between an element and other elements in the financial statements. So it can be concluded that financial ratio analysis is a tool used to measure the weaknesses and strengths faced by companies in the financial sector, by comparing one number with another from a financial report consisting of a balance sheet and profit / loss statement. In this case, the balance sheet describes the position of the company's assets, debt and equity, while the profit / loss statement provides an overview of the income and all costs and profits that occurred in a certain period. Furthermore, Sawir (2003: 7) states that: "Financial ratios are grouped into 5 (five) basic groups, namely liquidity, leverage, activity, profitability and market valuation.

\section{Profitability}

Profitability is the ability achieved by the company in a certain period. The basis for assessing profitability is a financial report consisting of a company's balance sheet and income statement. Based on the two financial statements, the results of the analysis of a number of ratios can be determined and then this ratio is used to assess certain aspects of the company's operations. Profitability analysis aims to measure the company's ability to earn profits, both in relation to sales, assets, and own capital. So the results of profitability can be used as a benchmark or a description of the effectiveness of management performance in terms of the benefits compared to the sales and investment results of the company. Financial reports such as balance sheets, income statements and cash flow are analyzed using analytical tools in accordance with the needs of the analyst. Financial analysis tools include: analysis of sources and use of funds, comparative analysis, trend analysis, Lavarege analysis, break even analysis, financial ratio analysis and 
others. Ratio is a method for assessing a company's financial condition based on ratio calculations based on quantitative analysis, which shows the relationship between one element and another in the income statement and balance sheet. In addition, company financial ratios are also used which allow comparing the ratio of a company with other similar companies or with industry average ratios.

\section{Du Pont}

The Du Pont and ROI systems are slightly different because in Du Pont, ROI is the Net Profit Margin multiplied by the asset turnover. Companies that develop this analysis system are often referred to as the Du Pont system or ROI with the Du Pont approach. This analysis emphasizes more on how much profit can be obtained with all the wealth owned by the company. The Du Pont system is used to analyze and improve company performance. The return on total assets tries to measure the company's effectiveness in utilizing resources which is sometimes called the return on investment (ROI). Based on the figure below, efforts to increase profits from sales can be investigated. Possibility of increasing prices to increase profit (or lower prices to increase sales volume). The Du Pont formula is used to control changes in activity ratios and net profit margins and how much they affect Return On Investment.

\section{Result and Discussion}

This research was conducted at the Palm Oil Mill company. The problems discussed in this study are regarding the assessment of the company's financial performance. The data to be analyzed are the financial statements consisting of the 2001-2005 balance sheet and income statement. Based on the discussion of the results of the research, the hypothesis that there was a decline in financial performance in 2001-2005 at PTPN XIV Palm Oil Mill in Luwu Regency was rejected because in 2001-2005 the financial performance at PTPN (PT Perkebunan Nusantara) XIV Palm Oil mill in the district had increased except in 2005.

Table 3. PTPN XIV Financial Balance Sheet in Luwu District 2001-2005

\begin{tabular}{cccc}
\hline year & Current asset & fix asset & Total asset \\
\hline 2001 & $38,761,790,391$ & $4,832,880,929$ & $43,594,671,320$ \\
2002 & $28,519,276,631$ & $7,797,928,957$ & $36,317,205,588$ \\
2003 & $23,761,790,391$ & $4,229,784,143$ & $27,991,574,534$ \\
2004 & $26,390,789,824$ & $5,286,421,458$ & $31,677,211,282$ \\
2005 & $25,697,889,942$ & $6,170,833,521$ & $31,868,723,463$ \\
\hline
\end{tabular}

This research was conducted at the Palm Oil Mill company. The problems discussed in this study are regarding the assessment of the company's financial performance. The data to be analyzed are the financial statements consisting of the 2001-2005 balance sheet and income statement

In 2001, every dollar of sales could generate a net profit of Rp. 0.191. Meanwhile, the funds that are invested in the total assets on average in one year rotate 1,312 times and the ability of the capital invested in the total assets will generate a net profit of $25.05 \%$.

In 2002, every dollar of sales could generate a net profit of Rp. 0.173. Meanwhile, the funds that are invested in the total assets in one year average rotate 2,429 times and the ability of the capital invested in the total assets will generate a net profit of $38.8 \%$. 
In 2003, every dollar of sales can generate a net profit of Rp. 0.138. Meanwhile, the funds that are invested in the total assets on average in one year rotate 3.26 times and the ability of the capital invested in the total assets will generate a net profit of $44.98 \%$.

In 2004 every dollar of sales can generate a net profit of Rp. 0.294. Meanwhile, the funds that are invested in the total assets on average in one year rotate 3,739 times and the ability of the capital invested in the total assets will generate a net profit of $109.85 \%$.

In 2005, every dollar of sales can generate a net profit of Rp. 0.162. Meanwhile, the funds that are invested in the total assets on average in one year rotate 2,881 times and the ability of the capital invested in the total assets will generate a net profit of $46.66 \%$.

\section{Methods}

This study is a study to determine the level of performance of PTPN XIV. In this study, the variables to be studied are: Net Profit Margin, Asset Turn Over, Net Income and Total Asset as measured by the Du Pont Method. To equalize opinions and perceptions, the operational definition of several variables is presented as follows: Du Pont system is a system used to analyze and improve company performance. Net Profit Margin is the percentage of profit capability obtained by the company Assets Turn Over is the ability of funds that are embedded in total rotating assets in a certain period Return on investment (ROI) is the company's ability to earn a profit from the assets used

PTPN XIV is a limited liability company or State-Owned Enterprise and is a company engaged in the cultivation of both oil palm and cocoa. Measurement of variables used in this research is the balance sheet and income for a period of five years, namely 2001 and 2005. The population is the whole of the object under study. So the population in this study is the company's financial statement data for the last 5 years, namely 2001-2005. This study uses time series data for the last five years, so that the population of this study is also the research sample. In this study, the authors used data collection techniques, namely interviews conducted to support the information needed by the researcher. Documentation, namely how to collect data, documents

\section{Conclusion}

Based on the results of the analysis stated in the previous chapter, several conclusions can be drawn as follows in 2001-2004 Return on Investment (ROI) experienced an increase due to an increase in sales during 2001-2004. There was a decrease in Return On investment in 2005 due to decreased sales results from 2004 to 2005. Financial analysis tools include: analysis of sources and use of funds, comparative analysis, trend analysis, Lavarege analysis, break even analysis, financial ratio analysis and others. Ratio is a method for assessing a company's financial condition based on ratio calculations based on quantitative analysis, which shows the relationship between one element and another in the income statement and balance sheet. In addition, company financial ratios are also used which allow comparing the ratio of a company with other similar companies or with industry average ratios.

\section{References}

Collis, David J and Montgomery, Cynthia A, 1997. Corporate Strategy, Resouces and the Scope of the Firm. McGrow-Hill Companies,USA

Dale, K. Ralph dan Fredeck Charles Kurz, 1962, Dasar-dasar Akuntansi, Terjemahan H. Muhiddin, Makassar : Yayasan Pendidikan Adhiputeri. 
Djarwanto. 1996. Proit Analysis. BPFE, Yogyakarta.

Foster, George. 1996. Financial Statement Analysis. Second Edition. Prentice Hall International, New Jersey.

Hanafi, M.M. dan Abdul Halim. 1996. Financial Statement Analysis.UUP AMP YKPN, Yogyakarta.

Harahap, Sofyan Safri. 2002. Critical Analysis of Financial Statements. Cetakan Ketiga.PT. Raja Grafindo Persada: Jakarta.

Horne, Van dan Wachowicz. 1997. Principles of Financial Management. Edisi

Indonesia oleh : Heru Sutojo, Salemba Empat, Jakarta.

Husnan, Suad \& Enny Pudjiastuti. 1998. Fundamentals of Financial Management. UPP AMP YKPN: Yogyakarta.

Husnan, Suad. 1996. Financial management. Buku Dua. Edisi Keempat, BPFE, Yogyakarta.

Keown, Arthur j.dkk, 2001, Fundamentals of Financial Management, Terjemahan Chaerul D. Djakman, Jakarta : Salemba Empat

Martono, 2003. Financial management Cetakan Ketiga. Penerbit EKONISIA:Yogyakarta.

Munawir, S., 2002, Analysis of financial statements, Edisi Keempat, Yogyakarta: Liberty

Rahardjo, Budi, 2000, Analysis of financial statements. Yogyakarta : Andi Offset

Riyanto, Bambang. 1999. Company spending basics. Edisi keempat. Yogyakarta: Penerbit BPFE.

Riyanto, Bambang. 2001. Company spending basics Cetakan Ketujuh. BPFE: Yogyakarta.

Sawir, Agnes. 2003. Financial Performance Analysis and Corporate Financial Planning. Cetakan Ketiga. PT, Gramedia Pustaka Utama: Jakarta.

Yamit, Zulian. 2001. Financial Management Summary of Theory and Problem Solving. Edisi Pertama. Cetakan kedua. Penerbit EKONISIA: Yogyakarta.

Copyright $\odot$ 2020, Journal of Asian Multicultural Research for Economy and Management Study, Under the license CC BY-SA 4.0 